Pacific Journal of Mathematics

COMPARISON OF HAAR SERIES WITH GAPS WITH 


\title{
COMPARISON OF HAAR SERIES WITH GAPS WITH TRIGONOMETRIC SERIES
}

\author{
J. R. McLaughlin and J. J. Price
}

\begin{abstract}
We study Haar series with gaps and show striking differences between these series and lacunary trigonometric series. For example, we prove that under certain gap conditions Haar series are finite series almost everywhere.
\end{abstract}

Haar's orthonormal system $\left\{\chi_{m}(t)\right\}$ is defined as follows on $[0,1]: \chi_{0}(t) \equiv 1$ and for $m=2^{n}+k$ with $0 \leqq k<2^{n}, n=0,1, \cdots$

$$
\begin{aligned}
\chi_{m}(t) & =2^{n / 2}, t \in\left(k / 2^{n},(k+1 / 2) / 2^{n}\right), \\
& =-2^{n / 2}, t \in\left((k+1 / 2) / 2^{n},(k+1) / 2^{n}\right), \\
& =0, t \notin\left[k / 2^{n},(k+1) / 2^{n}\right],
\end{aligned}
$$

and at the three remaining points we let $\chi_{m}(t)$ be equal to the average of the right and left hand limits. Thus, in contrast to the trigonometric system, if $2^{n} \leqq m<2^{n+1}$, the Haar function $\chi_{m}(t)$ is supported on an interval of Length $2^{-n}$ and

$$
\int_{0}^{1}\left|\chi_{m}(t)\right| d t=2^{-n / 2}
$$

For $f \in L(0,1)$ we call

$$
a_{m}(f)=\int_{0}^{1} f(t) \chi_{m}(t) d t, m=0,1, \cdots
$$

the Haar-Fourier coefficients of $f$ and $\sum_{m=0}^{\infty} a_{m}(f) \chi_{m}(t)$ the Haar-Fourier series of $f$.

P. L. Ul'janov has noted [8, p. 42] that if $\left\{m_{k}\right\}$ is an increasing sequence of positive integers for which $\sum\left(m_{k}\right)^{-1}$ converges, and if the gap series $\sum a_{m_{k}} x_{m_{k}}(t)$ is the Haar-Fourier series of a bounded function, then the series converges absolutely almost everywhere (cf. [9, p. 247]). The following theorem strengthens this result.

THEOREM 1. (i) If $\left\{a_{k}\right\}$ is any sequence of real numbers and $\left\{m_{k}\right\}$ is an increasing sequence of positive integers such that $\sum\left(m_{k}\right)^{-1}$ converges, then $\sum_{k=1}^{\infty} a_{k} \chi_{m_{k}}(t)$ is a finite series for almost every $t \in[0,1]$.

(ii) If $\sum\left(m_{k}\right)^{-1}$ diverges, then there exists a sequence of real numbers $\left\{a_{k}\right\}$ and an increasing sequence of positive integers $\left\{n_{k}\right\}$ satisfying

$$
\text { ( a ) } \sum_{k=1}^{N} \frac{1}{n_{k}} \leqq \sum_{k=1}^{N} \frac{1}{m_{k}} \text { for } \quad N=1,2, \cdots \text {, }
$$


(b) $\sum a_{k} \chi_{n_{k}}(t)$ is the Haar-Fourier series of $f \in L^{p}$, for all $p \in[1, \infty)$,

(c) $\sum\left|a_{k} \chi_{n_{k}}(t)\right|$ diverges for almost every $t \in[0,1]$.

Proof. Part (i). Let $E_{m}$ denote the support of $\chi_{m}(t)$ on $[0,1]$ for $m=2^{n}+k$ with $0 \leqq k<2^{n}, n=0,1, \cdots$. Then

$$
\frac{1}{m} \leqq \frac{1}{2^{n}}=\mu\left(E_{m}\right)<\frac{2}{m}
$$

where $\mu\left(E_{m}\right)$ denotes the measure of $E_{m}$. Thus, $\sum_{k=1}^{\infty} \mu\left(E_{m_{k}}\right)$ converges and consequently $\mu\left(\lim \sup _{k} E_{m_{k}}\right)=0$ [5, p. 40, Exercise 6].

Part (ii). Choose a sequence of real numbers $\left\{b_{k}\right\}$ satisfying

$$
\sum b_{k}^{2}<\infty \text { and } \sum\left|b_{k}\right|=\infty \text {. }
$$

Set

$$
f(t)=\sum_{k=1}^{\infty} b_{k} r_{p_{k}}(t)=\sum_{k=1}^{\infty} b_{k}\left(2^{p_{k}}\right)^{-1 / 2} \sum_{m=2^{p_{k}}}^{2^{p_{k}+1}} \chi_{m}(t)
$$

where $r_{m}(t)$ denotes the $m$ th Rademacher function [1, p. 51] and $\left\{p_{k}\right\}$ is an increasing sequence of positive integers. Now let $\left\{a_{k}\right\}$ and $\left\{n_{k}\right\}$ be defined by the right side of (2). Then if $\left\{p_{k}\right\}$ increases fast enough (a) holds. Also, since $\sum a_{k}^{2}$ converges, the right hand side of (2) is the Haar-Fourier series of its sum $f(t)$ [1, p. 47]. The remaining properties follow from (1) by well-known properties of Rademacher series $[9, p .213]$.

REMARK 1. It would be interesting to know if in condition (b) in Theorem 1 one might replace $f \in L^{p}$, for all $p \in[1, \infty)$, by $f$ continuous or even $f$ bounded.

REMARK 2. A. M. Olevskii has proved [6, p. 1382] that for every complete orthonormal system (and hence the Haar system) there exists a continuous functions whose Fourier series is absolutely divergent almost everywhere.

It is known [3, p. 243] that if a lacunary trigonometric series is the Fourier series of a function $f$, then $f \in L^{q}$ for every $q \in[1, \infty)$.

This result is not valid for Haar series as we now prove.

THEOREM 2. For every $p \geqq 1$, there exists a function $f \in L^{p}$ with Haar-Fourier series $\sum a_{m_{k}} \chi_{m_{k}}(t)$ where $m_{k+1} / m_{k}=2, k=1,2, \cdots$, and such that for every $q>p, f \notin L^{q}$. 


$$
f(t)=\left(2^{n} \cdot n^{-2}\right)^{1 / p} \quad \text { if } \quad t \in\left(2^{-n}, 2^{-n+1}\right), n=1,2, \cdots .
$$

Then

$$
\int_{0}^{1}|f(t)|^{n} d t=\sum_{n=1}^{\infty}\left(2^{n} \cdot n^{-2}\right) \cdot 2^{-n}<\infty
$$

but if $q>p$,

$$
\int_{0}^{1}|f(t)|^{q} d t=\sum_{n=1}^{\infty}\left(2^{n} \cdot n^{-2}\right)^{q / p} \cdot \mathcal{\Sigma}^{-n}=\infty .
$$

Also, the Haar-Fourier series of $f$ is

$$
a_{0}(f)+\sum_{h=0}^{\infty} a_{2^{k}}(f) \chi_{2^{k}}(t) .
$$

If a lacunary trigonometric series is a Fourier series with Fourier coefficients $\left\{c_{k}\right\}$, then $\sum c_{k}^{2}$ converges [9, p. 203]. As Theorem 2 shows, for Haar-Fourier series, this need not be. We can even obtain a stronger result.

Theorem 3. Let $\left\{a_{k}\right\}$ be any sequence of real numbers. Then there is a function in $L(0,1)$ with a gap Haar-Fourier series

$$
\sum_{k=1}^{\infty} a_{k} \chi_{m_{k}}(t)
$$

Proof. If $m=2^{n}+k$ with $0 \leqq k<2^{n}, n=0,1, \cdots$, then

$$
\int_{0}^{1}\left|\chi_{m}(t)\right| d t=2^{-n / 2}<2 m^{-1 / 2}
$$

and so there is a sequence of positive integers $\left\{m_{k}\right\}$ increasing so fast that

$$
\sum_{k=1}^{\infty}\left|\alpha_{k}\right| \int_{0}^{1}\left|\chi_{m_{k}}(t)\right| d t<\infty
$$

Hence, series (3) is the Haar-Fourier series of its sum by Lebesgue's dominated convergence theorem.

If a lacunary trigonometric series converges to zero in a set of positive measure, then all the coefficients of the series equal zero [3, p. 265]. For Haar series this result is not valid. In fact, we have the following.

Theorem 4. For every $t_{0} \in[0,1]$, there exists a gap Haar-Fourier series $\sum a_{m_{k}} \chi_{m_{k}}(t)$, where $m_{k+1} / m_{k} \geqq 2$, which converges to zero for 
$t \neq t_{0}$ and diverges for $t=t_{0}$.

Proof. If $t_{0}=1$, we set $a_{0}=-1, a_{2^{n+1}-1}=2^{n / 2}$ for $n=0,1, \cdots$, and $a_{m}=0$ otherwise.

If $t_{0} \in[0,1)$, then for the sequence of integers $\left\{k_{n}\right\}$ satisfying

$$
\left(k_{n}\right) 2^{-n} \leqq t_{0}<\left(k_{n}+1\right) 2^{-n}, \quad n=0,1, \cdots
$$

we set

$$
\begin{aligned}
a_{m} & =1, \quad m=0 \\
& =(-1)^{k_{n+1} 2^{n / 2}}, \quad m=2^{n}+k_{n}, \quad n=0,1, \cdots \\
& =0 \quad \text { otherwise. }
\end{aligned}
$$

Then, using the fact (which is easily proved inductively) that

$$
\begin{aligned}
\sum_{n=0}^{2^{n}-1} a_{m} \chi_{m}(t) & =2^{n}, \quad t \in\left(\left(k_{n}\right) 2^{-n},\left(k_{n}+1\right) 2^{-n}\right) \\
& =0, \quad t \notin\left[\left(k_{n}\right) 2^{-n},\left(k_{n}+1\right) 2^{-n}\right]
\end{aligned}
$$

for $n=0,1, \cdots$, we obtain our desired result.

Corollary. A nonempty set is a set of multiplicity for Haar series.

REMaRK 3. G. Faber had previously shown [4, p. 111] that the point $t_{0}=1 / 2$ was a set of multiplicity for Haar series. Also F. G. Arutjunjan and A. A. Talaljan noted Theorem 4 for $t_{0}=0$ [2, p. 1405]. On the other hand, M. B. Petrovskaja proved that the empty set is a set of uniqueness for Haar series [7, p. 797].

\section{REFERENCES}

1. G. Alexits, Convergence problems of orthogonal series, Pergamon Press, New York, 1961.

2. F. G. Arutjanjan, A. A. Talaljan, Uniqueness of series in Haar and Walsh systems (Russian), Izv. Akad. Nauk. SSSR Ser. Mat. 28 (1964), 1391-1408.

3. N. Bary, A Treatise on trigonometric series, vol. 2, Pergamon Press, New York, 1964.

4. G. Faber, Über die Orthogonalfunktionen des Herrn Haar, Jber. Deutsch. Math.Verein. 19 (1910), 104-112.

5. P. R. Halmos, Measure theory, Van Nostrand, New York, 1950.

6. A. M. Olevskiǐ, Divergent Fourier series for continuous functions, Soviet Math. Dokl. 2 (1961), 1382-1386=Dokl. Akad. Nauk SSSR 138 (1961), 545-548.

7. M. B. Petrovskaja, Null series of the Haar system and sets of uniqueness (Russian), Izv. Akad. Nauk. SSSR Ser. Mat. 28 (1964), 773-798.

8. P. L. Ul'janov, Haar series (Russian), Vestnik Moskov. Univ. Ser. I Mat. Meh. 
4 (1965), 35-43.

9. A. Zygmund, Trigonometric series, Vol. 1, Cambridge Univ. Press, New York, 1959. Received April 26, 1968.

Pennsyluania State University and

PuRdue UNIVERSity 



\section{PACIFIC JOURNAL OF MATHEMATICS}

\section{EDITORS}

\author{
H. ROYDEN \\ Stanford University \\ Stanford, California \\ R. R Phelps \\ University of Washington \\ Seattle, Washington 98105
}

\author{
J. Dugundui \\ Department of Mathematics \\ University of Southern California \\ Los Angeles, California 90007
}

RICHARD ARENS

University of California

Los Angeles, California 90024

\section{ASSOCIATE EDITORS}
E. F. BeCKENBACH
B. H. NeUmanN
F. WolF
K. YosidA

\section{SUPPORTING INSTITUTIONS}

\author{
UNIVERSITY OF BRITISH COLUMBIA \\ CALIFORNIA INSTITUTE OF TECHNOLOGY \\ UNIVERSITY OF CALIFORNIA \\ MONTANA STATE UNIVERSITY \\ UNIVERSITY OF NEVADA \\ NEW MEXICO STATE UNIVERSITY \\ OREGON STATE UNIVERSITY \\ UNIVERSITY OF OREGON \\ OSAKA UNIVERSITY \\ UNIVERSITY OF SOUTHERN CALIFORNIA
}

\author{
STANFORD UNIVERSITY \\ UNIVERSITY OF TOKYO \\ UNIVERSITY OF UTAH \\ WASHINGTON STATE UNIVERSITY \\ UNIVERSITY OF WASHINGTON

$* * * * *$
AMERICAN MATHEMATICAL SOCIETY
CHEVRON RESEARCH CORPORATION
TRW SYSTEMS
NAVAL WEAPONS CENTER

The Supporting Institutions listed above contribute to the cost of publication of this Journal, but they are not owners or publishers and have no responsibility for its content or policies.

Mathematical papers intended for publication in the Pacific Journal of Mathematics should be in typed form or offset-reproduced, double spaced with large margins. Underline Greek letters in red, German in green, and script in blue. The first paragraph or two must be capable of being used separately as a synopsis of the entire paper. It should not contain references to the bibliography. Manuscripts, in duplicate if possible, may be sent to any one of the four editors. Please classify according to the scheme of Math. Rev. 36, 1539-1546. All other communications to the editors should be addressed to the managing editor, Richard Arens, University of California, Los Angeles, California, 90024.

50 reprints are provided free for each article; additional copies may be obtained at cost in multiples of 50 .

The Pacific Journal of Mathematics is published monthly. Effective with Volume 16 the price per volume (3 numbers) is $\$ 8.00$; single issues, $\$ 3.00$. Special price for current issues to individual faculty members of supporting institutions and to individual members of the American Mathematical Society: $\$ 4.00$ per volume; single issues $\$ 1.50$. Back numbers are available.

Subscriptions, orders for back numbers, and changes of address should be sent to Pacific Journal of Mathematics, 103 Highland Boulevard, Berkeley, California, 94708.

PUBLISHED BY PACIFIC JOURNAL OF MATHEMATICS, A NON-PROFIT CORPORATION

Printed at Kokusai Bunken Insatsusha (International Academic Printing Co., Ltd.), 7-17. Fujimi 2-chome, Chiyoda-ku, Tokyo, Japan. 


\section{Pacific Journal of Mathematics}

Vol. 28, No. 3

May, 1969

Jon F. Carlson, Automorphisms of groups of similitudes over $F_{3} \ldots \ldots \ldots$

W. Wistar (William) Comfort, Neil Hindman and Stelios A. Negrepontis,

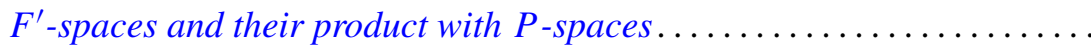

Archie Gail Gibson, Triples of operator-valued functions related to the unit

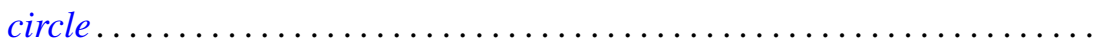

David Saul Gillman, Free curves in $E^{3}$

E. A. Heard and James Howard Wells, An interpolation problem for

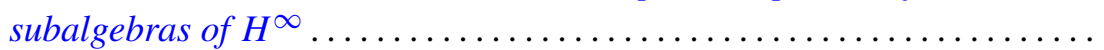

Albert Emerson Hurd, A uniqueness theorem for weak solutions of symmetric

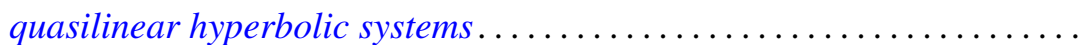

E. W. Johnson and J. P. Lediaev, Representable distributive Noether

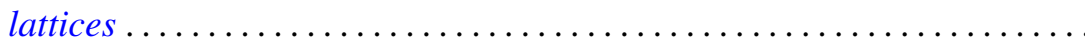

David G. Kendall, Incidence matrices, interval graphs and seriation in

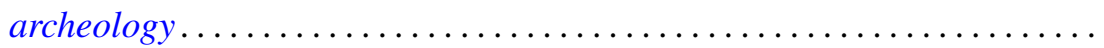
565

Robert Leroy Kruse, On the join of subnormal elements in a lattice ....... 571

D. B. Lahiri, Some restricted partition functions; Congruences modulo 3 .... 575

Norman D. Lane and Kamla Devi Singh, Strong cyclic, parabolic and conical differentiability........................................

William Franklin Lucas, Games with unique solutions that are

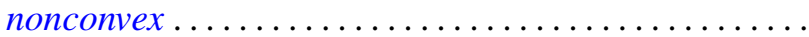

Eugene A. Maier, Representation of real numbers by generalized geometric series.

Daniel Paul Maki, A note on recursively defined orthogonal polynomials ...

Mark Mandelker, $F^{\prime}$-spaces and z-embedded subspaces ...

James R. McLaughlin and Justin Jesse Price, Comparison of Haar series with gaps with trigonometric series

Ernest A. Michael and A. H. Stone, Quotients of the space of irrationals ....

William H. Mills and Neal Zierler, On a conjecture of Golomb ...

J. N. Pandey, An extension of Haimo's form of Hankel convolutions ...

Terence John Reed, On the boundary correspondence of quasiconformal mappings of domains bounded by quasicircles...

Haskell Paul Rosenthal, A characterization of the linear sets satisfying Herz's criterion.

George Thomas Sallee, The maximal set of constant width in a lattice...

I. H. Sheth, On normaloid operators

James D. Stasheff, Torsion in BBSO ...

Billy Joe Thorne, A - P congruences on Baer semigroups.

Robert Breckenridge Warfield, Jr., Purity and algebraic compactness for

modules... 